\title{
Trafficking Protein Gene
}

National Cancer Institute

\section{Source}

National Cancer Institute. Trafficking Protein Gene. NCI Thesaurus. Code C26006.

Trafficking Protein Genes encode proteins involved in various cellular sorting and transport mechanisms - such as gated transport, protein translocation, and vesicular transport - whereby cellular proteins are positioned, sorted, and directed to, sequestered in, or moved from one cellular compartment to another specific correct subcellular cellular compartment for proper function. ( $\mathrm{NCl})$ 